\title{
Behavior of SS-316 in Engine Oil Simulated Environment
}

\author{
Gokul A K, Gokula Krishnan S, Adam Khan M, Anushraj B, Winowlin Jappes J T
}

\begin{abstract}
Oil pumps are facing aggressive environment during operation. The halides in the environment are ingested with the oil during operation. At this condition, the oil is heated up to $80^{\circ} \mathrm{C}$ and making the component to prove under corrosion. To simulate this issue, components from oil pump made of (SS 316 L) austenitic stainless steel. Engine oil before and after usage is considered as an electrolyte-to study the corrosion using cyclic Volta-metric potentiostat, corrosion studies are performed with pure and filtered oil. After corrosion studies, samples are analyzed from SEM for surface damage.
\end{abstract}

Keywords : corrosion, oil, steel, polarization, electrochemical.

\section{INTRODUCTION}

$\mathrm{I}$ recent research, austenitic stainless steels are attractive materials for diverse industrial sectors, to combat environmental and corrosive attack [1]. Motor oil, engine oil, or engine lubricants are having basic substances comprised of base oils with additives, anti-wear reagents, detergents and dispersants as multi-grade oil viscosity index improvers. Detergents that are part of the additive packages remove impurities to the oil filter, clean existing deposits and foreign substances in the engine, achieving engine cleanliness \& preventing it from serious damage. The oil forms a hydrodynamic film between metal surfaces, during wear friction between metal-to-metal contact and resulting in degradation of the engine components. Motor oil is used for lubrication of internal combustion engines. The main function of motor oil is to reduce friction and wear of the moving parts. Oil starvation is a major factor that is fatal to any engine, and is usually the result of a failed oil pump.

The interactions of sulfate and chloride present in the oil forming chemical reactions are of interest in this work. The presence of sulfate ions, in oil field strongly influenced corrosion mechanisms along with nitrogen alluring

Revised Manuscript Received on December 30, 2019.

* Correspondence Author

Gokul A K, Centre for Surface Engineering, Department of Mechanical Engineering, Kalasalingam Academy of Research \& Education, Virudhunagar, Tamilnadu, India, Email: gokul.babu28@gmail.com

Gokula Krishnan S, Centre for Surface Engineering, Department of Mechanical Engineering, Kalasalingam Academy of Research \& Education, Virudhunagar, Tamilnadu, India, Email: sgokulakrishnan09@gmail.com

Adam Khan M*, Centre for Surface Engineering, Department of Mechanical Engineering, Kalasalingam Academy of Research \& Education, Virudhunagar, Tamilnadu, India, Email: adamkhanm@gmail.com

Anushraj B, Centre for Surface Engineering, Department of Mechanical Engineering, Kalasalingam Academy of Research \& Education, Virudhunagar, Tamilnadu, India Email: anushrajb@gmail.com

Winowlin Jappes J T, Centre for Surface Engineering, Department of Mechanical Engineering, Kalasalingam Academy of Research \& Education, Virudhunagar, Tamilnadu, India Email: winowlin@klu.ac.ing

degradation. $\mathrm{NO}_{\mathrm{x}}$ created during combustion is an undesirable species in the oil. The oil turns saturated with soluble and/or insoluble nitrogen-oxide as a compound during service. The reaction of nitrogen with the base oil will allow forming (i) Organic nitrates, from cylinder wall and (ii) nitro compounds caused by a blow-by process when the gas reacts with the oil in the sump.

Corrosion mechanisms in oil field systems are complex and are showing high degrees of interaction between corrosion species, products, and oil field metallurgies. There are few research articles discussion about the effects of different lubrication environment [2-4], fluid concentration [5,6] and viscosity [7] on lubrication performance and machining efficiency.

Corrosive species found in lubricating oils include sulphur compounds, acidic combustion products (oxy-acids of nitrogen and sulphur), acidic oil oxidation products, water, and carbon dioxide. The use of EGR amplifies corrosion rates due to the formation of increased levels of sulphuric acid, by reaction of sulphur oxides with condensed water on the cylinder surfaces [8].

They are independent of the oxy-products that lead to oil oxidation, which is another form of oil degradation. The reaction between NOx and the oil, which causes nitration of the oil, occurs partially on the thin layer of oil on the cylinder wall. Base oils with saturated hydrocarbon structures, such as polyalphaolefin (PAO) and hydrotreated paraffinic seem to be less prone with nitration process. While there are many research works on the effects of $\mathrm{CO}_{2}$ and $\mathrm{H}_{2} \mathrm{~S}$ on corrosion of carbon steel, those of conjoint effects of $\mathrm{S}_{2^{-}}, \mathrm{Cl}$ - and $\mathrm{SO}_{4}$ - are much less. Due to impotence of carbon compositions in automobile industry the corrosion is finding as an adverse phenomenon because of the calamity on the behavior and properties of such metal variants. When conventional oil contaminants break down, they coat the components with varnish, various deposits and sludge and leave the lubricant thick, extremely hard to pump and with very poor ability to transfer heat as a result of increase in viscosity of oil. The viscosity change caused by thermal breakdown results in decreased oil flow, which can eventually lead to increased oil consumption, deposit buildup and damage to the engine's metal surfaces. Crude oil has a significant effect of the corrosion of steel in crude oil/brine mixtures, and these effects depend on respective oil natures. To improve the conductivity of metals with crude oil, $3.5 \% \mathrm{NaCl}$ in $20 \mathrm{ml}$ of distilled water was added [9]. 


\section{Behavior of SS-316 in Engine Oil Simulated Environment}

The electrolytes used for the electrochemical testing of austenitic Stainless-steel-316 samples are Pure Engine-Oil and Filtered Engine-Oil. These are synthetic type of Engine oil used for lubrication purposes, commercially in Automobiles. "20W-40" is a code for multi grade oil (according to SAE). The "W" indicates it is multi-viscosity motor oil. The "20" indicates that it has the viscosity of 20 weight motor oil in cold temperatures, and the " 40 " is the comparable viscosity during hot temperatures. The properties of the multi-grade synthetic oil are of high and maximize performance, high viscosity index, high dirt dispensing capacity, excellent cleaning capacity and of high thermal stability. Prolonged exposure of the metal in the oil environment results in pitting on the surfaces of the metal thereby degradation of the material is noticed. From the survey on existing research, the study on SS-316 with engine oil and brine solution is missing. The experimental analysis was performed based on studies.

\section{EXPERIMENTAL PROCEDURE}

\section{A. Electrodes and Solutions}

The rectangular $(1.5 \mathrm{~cm} \times 1.5 \mathrm{~cm})$ stainless steel electrode for electrochemical tests was made of a sheet of SS-316 steel, a commonly used steel in metallurgical industries, with the chemical composition (wt, \%): C 0.08, Si 0.75, Mn 2, P 0.045, S 0.03 , Mo 2-3,Cr 16-18, Ni 10-14 and Fe balance. Prior to the tests, the working surface of the sample was ground to 800 grit emery paper, then consequently polished with 1200 grit and finally cleaned by ethanol and deionized water.

During electrochemical tests, the working electrode was kept in the oil under the test conditions for 5 min to make the electrode reach the steady-state, which was indicated by the relatively stable values of the observed corrosion potential. In order to increase the conductivity of engine oil, $3.5 \%$ of $\mathrm{NaCl}$ solution is added. All the tests were open to air to assume fully aerated surroundings and performed at the ambient temperature with the exception of investigations of the effect of temperature on corrosion of the steel for certain test conditions.

\section{B. Heat Treatment Processes}

The Stainless steel (Grade-316) is heat treated (Annealing) using the tubular furnace inside which the polished metal samples of $(1.5 \mathrm{~cm} \times 1.5 \mathrm{~cm})$ size are kept for hours based on the thermal cycle representation of Stainless steel

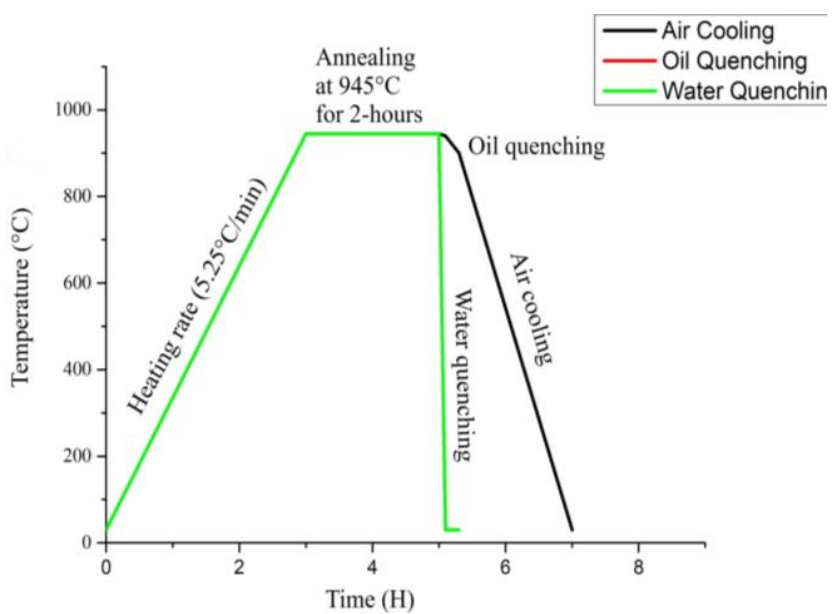

Fig 1: Plan for Heating \& Quenching by three different medium

The samples are heated to $925^{\circ} \mathrm{C}$ at a heating rate of $5.25^{\circ} \mathrm{C} / \mathrm{min}$ and hold at $2 \mathrm{hrs}$. The samples after annealing are quenched by three variations: Oil quench; Water quench; and Air cooled which are then subjected to corrosion analysis. Best results of the three quenched metals are noticed, which are further immersed in motor Oil and periodically tested for its results.

\section{Electro-Chemical Measurements}

Electrochemical measurements were conducted using electro-chemical analyzer coupled with analyst software, controlled by a personal computer, in conventional three-electrode cell systems. The electrochemical polarization measurement was carried out using potentiostat/galvanostat (ACM instruments GillAC, UK) comprising of three electrode cells with an arrangement of saturated calomel electrode as a reference, platinum sheet as a counter electrode, and the sample as a working electrode. The ASTM standard ASTM G3-14 practice for conventional electrochemical measurements procedures was followed. The area of exposure was $1 \mathrm{~cm}^{2}$ at room temperature and at certain test temperature ranges. The medium of exposure for corrosion measurement is of two kinds (pure and filtered) of synthetic engine oil samples. Experiments were performed in different concentrations of engine oil variants, at preselected viscosity and temperature, to determine the corrosion potential (Ecorr), corrosion current (icorr) and Corrosion rates $(\mathrm{CR})$ of the samples in the unit of $\mathrm{mm} /$ Year. After getting a stable open circuit potential, the polarization curves were measured by sweeping the potential from $-250 \mathrm{~V}$ to 250 $\mathrm{V}(\mathrm{SCE})$ at a sweep rate of $1 \mathrm{mV} / \mathrm{s}$.

The Tafel plot was obtained after conducting the electrochemical polarization measurements. The exposed samples after polarization measurement were further subjected to immersion periodically for further experimentation. The scanning electron microscope (Make: Zeiss-FE SEM) and SEM attached with energy-dispersive spectroscopy (Make: Brukers EDS) are used for characterization analysis. 


\section{RESULTS AND DISCUSSION}

\section{A. Electrochemical Polarisation Studies for Bare SS-316 with Pure/Filtered Engine Oil}

The samples being subjected to specified potential either anodic or cathodic are excited on the metal surface upon contact with pure/filtered oil. Studies are related to the primary electrochemical process.

Table I: Results of Polarization studies for Bare SS-316 metal exposed in Pure oil

\begin{tabular}{|l|l|l|l|l|}
\hline $\begin{array}{l}\text { Test } \\
\text { Condition }\end{array}$ & $\begin{array}{l}\text { Rest } \\
\text { Potential } \\
(\mathrm{mV})\end{array}$ & $\begin{array}{l}\mathrm{I}_{\text {corr }} \\
\left(\mathrm{mA} / \mathrm{cm}^{2}\right)\end{array}$ & $\begin{array}{l}\mathrm{E}_{\text {corr }} \\
(\mathrm{mV})\end{array}$ & $\begin{array}{l}\text { Corrosion } \\
\text { Rate } \\
(\mathrm{mm} / \mathrm{Yr})\end{array}$ \\
\hline First day & -1241.4 & 0.1624955 & -1653.8 & 2.1644 \\
\hline After 5 days & -3128.65 & 0.0592108 & -7783.4 & 3.8621 \\
\hline After 10-days & -3894.3 & 0.0050355 & -5564.7 & 6.3854 \\
\hline
\end{tabular}

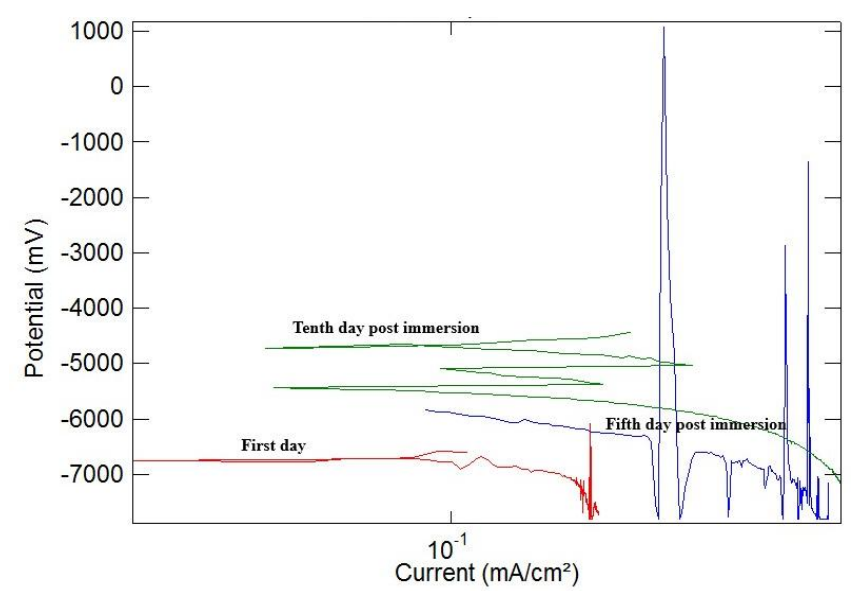

Fig 2: The polarization graph obtained for the bare metal exposed to pure engine oil

Table II: Results of Polarization studies for Bare SS-316 metal exposed in Filter oil

\begin{tabular}{|l|l|l|l|l|}
\hline $\begin{array}{l}\text { Test } \\
\text { Condition }\end{array}$ & $\begin{array}{l}\text { Rest Potential } \\
(\mathrm{mV})\end{array}$ & $\begin{array}{l}\text { Icorr } \\
\left(\mathrm{mA} / \mathrm{cm}^{2}\right)\end{array}$ & $\begin{array}{l}\text { Ecorr } \\
(\mathrm{mV})\end{array}$ & $\begin{array}{l}\text { Corrosion } \\
\text { Rate } \\
(\mathrm{mm} / \mathrm{Yr})\end{array}$ \\
\hline First day & -2813.3 & 0.2763527 & -5022.8 & 3.6876 \\
\hline After 5 days & -4531.56 & 0.3902816 & -7431.2 & 5.1985 \\
\hline After 10-days & -4265.97 & 0.567289 & -9767.4 & 9.7328 \\
\hline
\end{tabular}

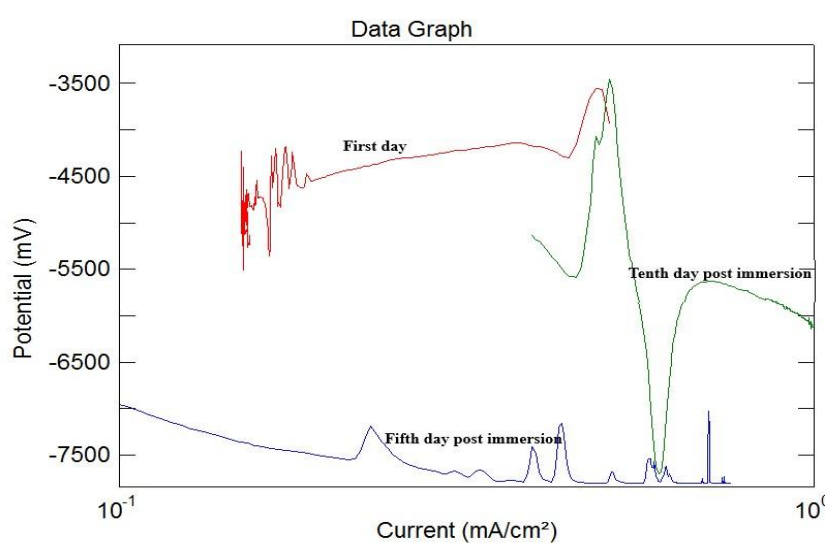

Fig. 3: The potentiodynamic polarisation graph obtained for the bare metal exposed to filtered engine oil, immersed periodically \& tested.

The potentiodynamic polarisation curve obtained for the bare metal, Stainless steel-316 exposed to pure oil \& filtered oil samples are shown in Fig. 2 \& 3. The bare metal exposed to pure/filtered oil has undergone slightly pitting corrosion. The experimental results define that the graphs obtained are unstable, due to which heat-treatment studies are focused. The corrosion rate is in increasing rate when the sample is exposed in the oil. This has been controlled by the Heat-treatment (Annealing) \& quenching processes for the investigation. Its respective corrosion density $\left(\mathrm{I}_{\text {corr }}\right)$, corrosion potential $\left(\mathrm{E}_{\text {corr }}\right)$, and CR calculated using the Tafel extrapolation method (through inbuilt software) are given in Table I \& II.

The potentiodynamic polarization measurements were performed on a three-electrode electro-chemical analyzer. The electrodes were positioned in the cell through the pre-opened mouths. An arrangement was made to fix the sample rigidly such that the surface of sample is exposed to electrolyte (Oil) at $1 \mathrm{~cm}^{2}$. The materials subjected to specified potential either anodic or cathodic those are being impressed on the surface of the metal with respect to the primary electrochemical process are studied. Figure 4 infers the surface morphology of sample exposed in pure oil. The corrosion is takes place in the form of uniform erosion takes place on the surface. Figure 5 shows the SEM image of sample exposed in filter oil. Corrosion takes in the form of pitting and huge crater forms on the surface. It is clearly identifies that in pure oil the corrosion is less and in filter oil the corrosion rate is heavy.

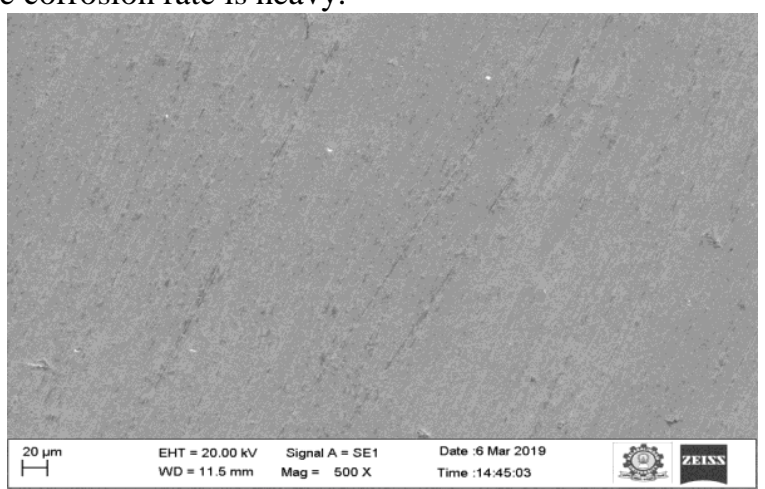

Fig 4: SEM image showing surface morphology of the Bare SS-316 exposed in pure oil test conditions.

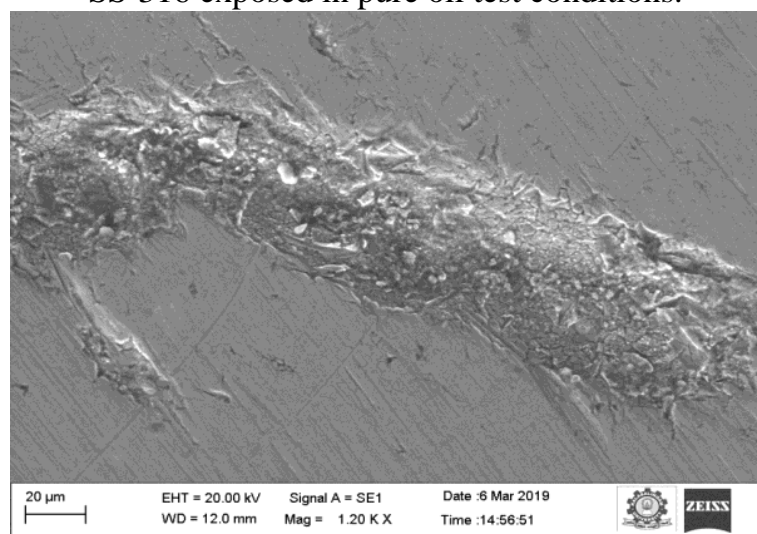

Fig 5: SEM image showing surface morphology of the Bare SS-316 exposed in Filtered oil test conditions 


\section{Behavior of SS-316 in Engine Oil Simulated Environment}

\section{B. Electrochemical Polarisation Studies for Heat Treated SS-316 with Pure/Filtered engine oil}

The samples are annealed and cooled in three different conditions. The three different conditions are air cooled, water quenched and oil quenched. The three condition of sample are then subjected to electrochemical analysis. The following results are obtained in table III.

The table IV illustrates the polarization data obtained for the sample exposed in pure and filter engine oil for the oil quenched condition. The corrosion rate is very high for the sample exposed in oil. The table $\mathrm{V}$ illustrates the polarization data obtained for the sample exposed in pure and filter engine oil for the water quenched condition.

Table III: Results of Polarization studies for Air cooled SS-316 with Pure/Filtered engine oil

\begin{tabular}{|l|l|c|c|c|c|}
\hline \multirow{2}{*}{$\begin{array}{c}\text { Test } \\
\text { Condition }\end{array}$} & $\begin{array}{c}\text { Test } \\
\text { Cases }\end{array}$ & $\begin{array}{c}\text { Rest } \\
\text { Potential } \\
(\mathrm{mV})\end{array}$ & $\begin{array}{c}\text { Icorr } \\
\left(\mathrm{mA} / \mathrm{cm}^{2}\right)\end{array}$ & $\begin{array}{c}\text { Ecorr } \\
(\mathrm{mV})\end{array}$ & $\begin{array}{c}\text { CR } \\
(\mathrm{mm} / \mathrm{Yr})\end{array}$ \\
\hline \multirow{2}{*}{ First Day } & Pure oil & -7795.12 & 0.098107 & -7247.5 & 1.3068 \\
\cline { 2 - 6 } & $\begin{array}{l}\text { Filtered } \\
\text { oil }\end{array}$ & -2533.96 & 0.119587 & -3102.8 & 1.5929 \\
\hline \multirow{2}{*}{$\begin{array}{l}\text { After } \\
\text { 5-days }\end{array}$} & Pure oil & -4087.7 & 0.253409 & -5583.4 & 3.3754 \\
\cline { 2 - 7 } & $\begin{array}{l}\text { Filtered } \\
\text { oil }\end{array}$ & -2350.92 & 0.321595 & -5241.6 & 4.2836 \\
\hline \multirow{2}{*}{$\begin{array}{l}\text { After } \\
\text { 10-days }\end{array}$} & Pure oil & -4735.87 & 0.312509 & -6572.4 & 4.1626 \\
\cline { 2 - 7 } & $\begin{array}{l}\text { Filtered } \\
\text { oil }\end{array}$ & -5523.65 & 0.415092 & -7455.1 & 5.529 \\
\hline
\end{tabular}

Table IV: Results of Polarization studies for Oil Quenching SS-316 with Pure/Filtered engine oil

\begin{tabular}{|l|l|l|l|l|l|}
\hline \multirow{2}{*}{$\begin{array}{l}\text { Test } \\
\text { Condition }\end{array}$} & $\begin{array}{l}\text { Test } \\
\text { Cases }\end{array}$ & $\begin{array}{l}\text { Rest } \\
\text { Potential } \\
(\mathrm{mV})\end{array}$ & $\begin{array}{l}\text { Icorr } \\
\left(\mathrm{mA} / \mathrm{cm}^{2}\right)\end{array}$ & $\begin{array}{l}\text { Ecorr } \\
(\mathrm{mV})\end{array}$ & $\begin{array}{l}\text { CR } \\
(\mathrm{mm} / Y r)\end{array}$ \\
\hline \multirow{2}{*}{ First Day } & Pure oil & -5136.19 & 0.139655 & -7797.9 & 1.8601 \\
\cline { 2 - 6 } & $\begin{array}{l}\text { Filtered } \\
\text { oil }\end{array}$ & -3942.56 & 0.158637 & -6753.4 & 2.0124 \\
\hline \multirow{2}{*}{$\begin{array}{l}\text { After 5- } \\
\text { Days }\end{array}$} & Pure oil & -4635.93 & 0.177738 & -7423.6 & 2.3674 \\
\cline { 2 - 6 } & $\begin{array}{l}\text { Filtered } \\
\text { oil }\end{array}$ & -3581.65 & 0.000185 & -6087.9 & 2.6487 \\
\hline \multirow{2}{*}{$\begin{array}{l}\text { After } \\
\text { 10-Days }\end{array}$} & Pure oil & -4644.62 & 0.242109 & -6289.8 & 3.2249 \\
\cline { 2 - 7 } & $\begin{array}{l}\text { Filtered } \\
\text { oil }\end{array}$ & -3893.4 & 0.000176 & -6591.8 & 6.3547 \\
\hline
\end{tabular}

Table 5: Results of Polarization studies for Water Quenching SS-316 with Pure/Filtered engine oil

\begin{tabular}{|l|l|l|l|l|l|}
\hline \multirow{2}{*}{$\begin{array}{l}\text { Test } \\
\text { Condition }\end{array}$} & $\begin{array}{l}\text { Test } \\
\text { Cases }\end{array}$ & $\begin{array}{l}\text { Rest } \\
\text { Potential } \\
(\mathrm{mV})\end{array}$ & $\begin{array}{l}\text { Icorr } \\
\left(\mathrm{mA} / \mathrm{cm}^{2}\right)\end{array}$ & $\begin{array}{l}\text { Ecorr } \\
(\mathrm{mV})\end{array}$ & $\begin{array}{l}\text { Corrosio } \\
\text { n Rate } \\
(\mathrm{mm} / \text { Yr })\end{array}$ \\
\hline \multirow{2}{*}{ First Day } & Pure oil & -2654.89 & 0.144548 & -5261.6 & 1.9253 \\
\cline { 2 - 6 } & $\begin{array}{l}\text { Filtered } \\
\text { oil }\end{array}$ & -5096.42 & 0.151502 & -7543.1 & 2.018 \\
\hline \multirow{2}{*}{$\begin{array}{l}\text { After } \\
\text { 5-days }\end{array}$} & Pure oil & -4486.87 & 0.248269 & -6430.5 & 3.3069 \\
\cline { 2 - 6 } & $\begin{array}{l}\text { Filtered } \\
\text { oil }\end{array}$ & -4757.73 & 0.377355 & -5639.4 & 5.0263 \\
\hline $\begin{array}{l}\text { After } \\
\text { 10-days }\end{array}$ & Pure oil & -4196.21 & 0.337441 & -6569.6 & 4.494 \\
\cline { 2 - 7 } & $\begin{array}{l}\text { Filtered } \\
\text { oil }\end{array}$ & -3335.07 & 0.541205 & -8670.3 & 7.2088 \\
\hline
\end{tabular}

\section{Comparison of Corrosion Rate}

Figure 6 infers the comparison of corrosion rate for the sample exposed in pure oil for the different cooling condition. The corrosion rate is very high for the water quenched condition and low for oil quenched condition.

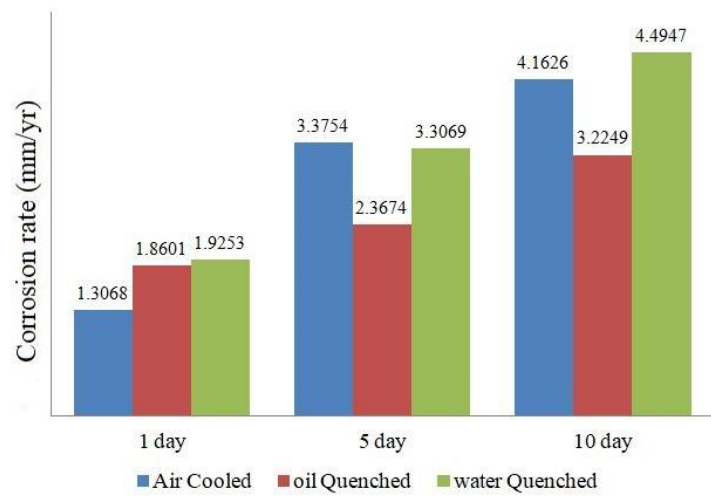

Fig 6: Comparison of Corrosion rate with Heat Treatment Condition for Pure Oil

For air cooled and water quenched condition the corrosion rate is very low for the first day and prolongs exposure to oil the corrosion rate is increased drastically. The corrosion rate is very in all the cases for the sample exposed in water quenched condition. In oil quenched condition the corrosion rate is increased slightly for the prolong exposure of sample.

The comparison of corrosion rate for the sample exposed in filter oil for different cooling condition is shown in figure 7 . The corrosion rate is slightly high when compared to pure oil. The air cooled sample on the first day the corrosion rate is high when prolongs exposure the corrosion rate is increased when compared to other cooling condition. The water quenched sample the corrosion rate is high in all the cooling condition. To improve the corrosion resistance of the SS-316 stainless steel is oil quenching is preferable.

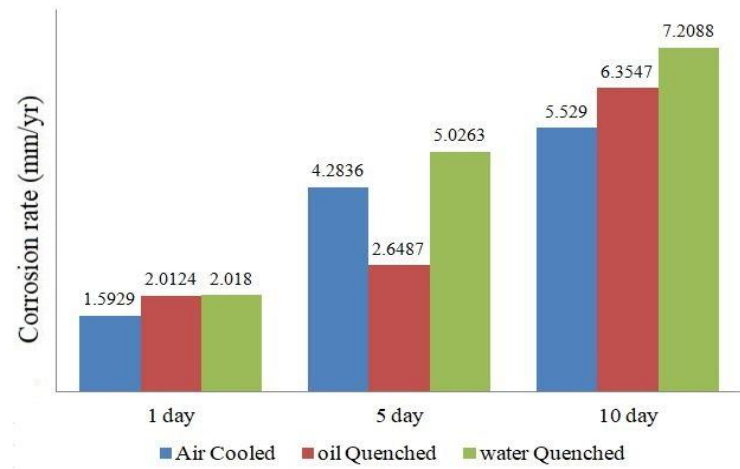

Fig 7: Comparison of Corrosion rate with Heat Treatment Condition for Filter Oil

\section{CONCLUSION}

The corrosion potential goes positive for the heat-treated sample which indicates that the annealed samples exhibit better corrosion resistance than the bare metal. The measured current density and the calculated CR are always normally proportional under this potentiodynamic polarisation study [16]. The corrosion density $\left(\mathrm{I}_{\text {corr }}\right)$ of the bare metal susceptible to pure oil is maximum $\left(0.3902816 \mathrm{~mA} / \mathrm{cm}^{2}\right)$ and that of filtered oil is maximum $\left(0.567289 \mathrm{~mA} / \mathrm{cm}^{2}\right)$. Water quenched $\left(0.3374415 \mathrm{~mA} / \mathrm{cm}^{2}\right)$, Oil quenched $\left(0.2421096 \mathrm{~mA} / \mathrm{cm}^{2}\right)$ and Air cooled $\left(0.3125099 \mathrm{~mA} / \mathrm{cm}^{2}\right)$ heat-treated samples. 
The corrosion rate in pure oil is very low when compared to filter oil. The sample quenched in oil gives the better corrosion resistance than the other cooling condition.

\section{REFERENCES}

1. T. Bell, Surface engineering of austenitic stainless steel.

2. N. Dhar, S. Paul, A. Chattopadhyay, The influence of cryogenic cooling on tool wear, dimensional accuracy and surface finish in turning AISI 1040 and E4340C steels, Wear 249 (2001) 932-942.

3. S.K. Bhambri, Journal of Material Science 21 (1986) 1741-1746.

4. N. Suresh Kumar Reddy, P. Venkateswara Rao, Experimental investigation to study the effect of solid lubricants on cutting forces and surface quality in end milling, Int. J. Machine Tools Manuf. 46 (2006) 189-198.

5. P. Vamsi Krishna, D. Nageswara Rao, Performance evaluation of solid lubricants in terms of machining parameters in turning, Int. J. Machine Tools Manuf. 48 (2008) 1131-1137.

6. V.Vasu, G.P.K.Reddy, Effect of minimum quantity lubrication with $\mathrm{A} 12 \mathrm{O} 3$ nanoparticles on surface roughness, tool wear and temperature dissipation in machining Inconel 600 alloy, Proc. Instit. Mech. Eng., Part N 225 (2011) 3-16

7. R.S. Gunerkar, P. Kuppan, Experimental Investigation of Vegetable Oil Based Cutting Fluid During Turning of SS316L, Int. J. Mech. Eng. Robotics (IJMER) 1 (2013) 46-52.

8. R Penchaliah, T J Harvey, R J K Wood, K Nelson, and H E G Powrie, The effects of diesel contaminants on tribological performance on sliding steel on steel contacts.

9. K. D. Efird, R. J. Jasinski, Effect of the Crude Oil on Corrosion of Steel in Crude Oil/Brine Production.

\section{AUTHORS PROFILE}

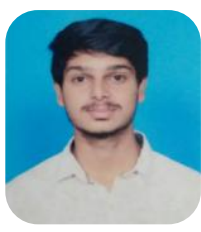

Mr. Gokul A $\mathbf{K}$ received his B.E Degree with distinction in Mechanical Engineering from Kalasalingam Academy of research and Education, India in 2019.

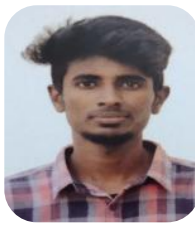

Mr. Gokula Krishnan S received his B.E degree with first class in mechanical engineering from Kalasalingam Academy of research and Education, India in 2019.

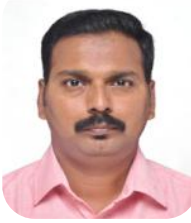

Dr. Adam Khan $\mathbf{M}$ is a Post-Doctoral Researcher from the Department of Mechanical and Industrial Engineering Technology, University of Johannesburg, South Africa. He received his Doctoral Degree from National Institute of Technology, Tiruchirappalli, India for his research in Surface Engineering studies on high temperature materials. His Bachelor (B.E.) and Master Degree (M.E.) from Anna University, Chennai in the specialization of Production and Design. Dr. Adam Khan research is focused on surface engineering and metallurgical analysis on processed materials. He has published 38 technical articles in different journals of international repute.

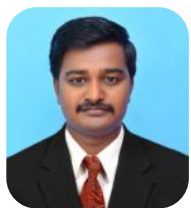

Mr. Anushraj B graduated in 2012 from St.Xavier's Catholic College of Engineering, India. In 2014, he received his M.E Degree in Energy Engineering from Regional Campus of Anna University, Tirunelveli, India. Currently, he is a research scholar at Kalasalingam Academy of Research and Education, India.

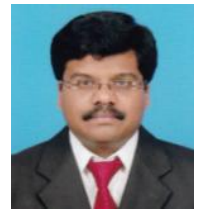

Dr. Winowlin Jappes J T graduated in 1997 from Manonmaniam Sunderanar University, India in Mechanical Engineering. In 1999, he has completed his masters in Production Engineering from Annamalai University. He completed his Ph.D degree in 2004 in the area of Composite Deposition at Indian Institute of Technology Madras, Chennai. He has completed three DST funded research projects and published more than 125 research articles which include 65 International Journal papers. Currently, he is working as Senior Professor in Kalasalingam University, India. His research interest includes high performance composite materials, machining of hard materials, optimization techniques, etc. At present, he is working as Professor and Dean, School of Automotive and Mechanical Engineering, Kalasalingam Academy of Research and Education, India. 